\title{
Temperature Influence on Species Co-Occurrence Patterns in Treefall Gap and Dense Forest Ant Communities in a Terra- Firme Forest of Central Amazon, Brazil
}

\author{
by \\ Wesley Dáttilo ${ }^{1^{*}}$ and Thiago J. Izzo ${ }^{1}$
}

\begin{abstract}
In this study we evaluated the influence of temperature and species co-occurrence on the structure of an ant community of treefall gaps and surrounding dense forests in a terra-firme forest of Central Amazon, Brazil. For this, we collected ants at different hours, and at the time of each collection we measured the temperature of the environment. Even with the difference in the temperature variation and variation throughout the day, there was nodifference in the richness and abundance of ants among the environments. Also, the ant species are distributed randomly and independently of one another in both studied environments in accordance with a null model (C-score). However, although not influenced by temperature, the ant composition of treefall gaps was different from the ant community of the surrounding dense forest. Possibly the composition and ant foraging in environments of treefall gaps and surrounding dense forests are not only influenced by temperature, but also by the interaction of this factor with the structural complexity of vegetation in terms of sites available for nesting and feeding, and other microclimatic factors. This generates a difference in ant composition of both environments. In addition, the structuring of ant community in tropical rain forests may actually be stochastic or neutral within each environment.

Key Words: Tropical Rain Forest; Formicidae; Microclimatic factors; Competition; Diversity.
\end{abstract}

\section{INTRODUCTION}

In the tropics, most small natural forest disturbances are caused by falling trees, forming natural treefall gaps (Uhl et al. 1978, Brokaw 1985, Almeida

\footnotetext{
${ }^{1}$ Departament of Ecology and Botany, Insect-Plant Interactions Lab., Universidade Federal de Mato Grosso, 78060-900. Cuiabá, Mato Grosso, Brazil.

*Email: wdattilo@hotmail.com
} 
1989). This stochastic event is part of the natural forest dynamic and acts as an additional factor in forest structure, changing the light intensity, temperature and humidity in these sites (Whitmore 1978, Brown 1993, Allen \& Meyer 1998). When this new habitat is formed, several adapted organisms can colonize these sites, replacing one another in succession (Probert 1993, Ekstam \& Forseby 1999, Andrade 2000). Among these organisms, ants emerge as one of the most prominent groups (Ward 2006). Because of their extreme abundance and diversity, ants act in the process of nutrient cycling, seed dispersal and aeration in the soil surface, and interact in various ways with other parts of the ecosystem, influencing the pattern of distribution and abundance of other taxa along succession (Hölldobler \& Wilson 1990, Majer \& Camer-Pescl 1991, Dáttilo et al. 2009).

In tropical rain forests, the ant diversity is extremely high, reaching approximately 500 species in only one collection site (Wilson 1959, Fisher 1999, Vasconcelos \& Delabie 2000, Longino et al. 2002). The success of these organisms is mainly due to several ecological and social adaptations, including generalized feeding and nesting habits (Benson \& Harada 1988, Hölldobler $\&$ Wilson 1990, Fowler et al. 1991). The high abundance and diversity of ants in tropical rain forests is also due to the high habitat complexity (abundance of places to nesting) and the climate stability in tropical regions over space and time, creating an ideal environment where several species specialists can establish (Benson \& Harada 1988, Hölldobler \&Wilson 1990, Reyes-Lopes et al. 2003). However, little is known about the relationship between the natural dynamics of tropical rainforests and the ant communities inside forests.

In many cases ant colonies are considered modular organisms and, in analogy, comparable to plants. This comparison is made because most ant species do not present migration behavior of the colony and their foraging is centered at a point (Andersen 1991, López 1994, Santos et al. 2006). Thus, competition has been identified as an important factor in the structure of ant communities (Andersen 1992, Adams 1994, Acosta et al. 1995, Punttila et al. 1996). The distribution of ant mosaics proposed by Room (1971) is defined as the distribution in patches of dominant ant species with similar ecological requirements, and therefore there is no overlap of their territories (Gause 1934, MacArthur \& Levins 1964, Chesson 2000). Thus, in small spatial scales is possible that competitive exclusion occurs with some ant species 
(Andersen 1995, Parr et al. 2000). However, beyond the competition, one of the factors that regulates the ant diversity and their foraging is the species' preference for different abiotic conditions, and several studies indicate that soil temperature is directly related to the foraging of these organisms on the soil surface (Porter \& Tschinkel 1987, Marsh 1988, Andersen 1992, Wehner et al. 1992, Cerdá et al. 1998).

Due to the fact that after the opening of a clearing there is an increase in daily temperature fluctuations on the soil surface (Vázquez-Yanes \& OrozcoSegovia 1982), and that the ants are sensitive to small microclimatic changes in the environment which they live (Brown 1997, Cerdá et al. 1997, 1998, Bestelmeye 2000), different adaptive strategies of ants that live in these two environments are expected (Aguiar \& Monteza 1996). Thus, in this study, we evaluated the influence of temperature and co-occurrence structuring the ant community of treefall gaps and surrounding dense forests in a terra-firme forest of Central Amazon, Brazil.

\section{MATERIAL AND METHODS}

\section{Study area}

This study was conducted during June and July 2007 in the forest reserve $\# 1501 \#\left(54^{\circ} 50^{\prime} \mathrm{W}\right.$ and $\left.02^{\circ} 25^{\prime} \mathrm{S}\right)$, located approximately $80 \mathrm{~km}$ north of Manaus city, Amazonas State, Brazil. The reserve area covers 10,000 ha of continuous forest, surrounded by a much larger area of undisturbed forest, and is part of the Biological Dynamics of Forest Fragments Project, BDFFP (INPA/Smithsonian Institution). Characterized as a primary tropical rainforest and terra-firme, it has canopy trees ranging from $30-40 \mathrm{~m}$ in height and some emergent trees which reach $50 \mathrm{~m}$ in height. The understory is relatively open and contains several species of palm trees (Lovejoy \& Bierregaard 1990). According to the Köppen classification, the climate is tropical humid (Afi) with average annual temperature of $26.7^{\circ} \mathrm{C}, 85 \%$ humidity and $2.200 \mathrm{~mm}$ of precipitation, with periods of rain between November and May and a dry season between June and October (Ribeiro 1976, Lovejoy \& Bierregaard 1990, Laurance 2001).

\section{Data collection}

Five treefall gaps and five surrounding dense forests were randomly selected approximately 300-800m away from each other. All treefall gaps had an area 
exceeding $400 \mathrm{~m}^{2}$ and were opened between 5 and 10 years before the present study (T.J. Izzo, pers. obs.). In each site three baits were distributed with $5 \mathrm{~g}$ of sardines and guava in a plastic card $10 \mathrm{~m}$ apart from each other, forming a triangle. After an hour, all the ants present in the baits were collected. The collections were made at five different hours (7h, 10h, 14h 18h, 22h), and at the time of each sample we measured the temperature, always at a height of $5 \mathrm{~cm}$ above the ground. The ants collected were stored in $70 \%$ alcohol for further identification. All individuals collected were deposited in the Entomological Collection of Instituto Nacional de Pesquisas da Amazônia (CE-INPA).

\section{Data analysis}

In order to not overestimate the ant species with more efficient systems for recruiting and / or those whose colonies are closer to the bait (Romero \& Jaffé 1989, Leal \& Lopes 1992, Tavares et al. 2001, Gotelli et al. 2011), all quantitative matrices used in this study were calculated based on the frequency of species occurrence in the bait and not based on the number of workers.

Initially, we tested the temperature variation among the times of the two environments using an Analysis of Variance with repeated measurements (ANOVA Repeated). Subsequently, we used General Linear Models (GLM) to assess the influence of temperature, the type of environment, and the interaction of both factors on the richness and abundance of ants, through the software SYSTAT 10.0.0 (Wilkinson 1998). To summarize the composition of the ant community foraging in environments of treefall gaps and surrounding dense forests, we ordered the similarity between points using Non-Metric Multidimensional Scaling (NMDS). This type of ordination analysis is one of the most robust and often summarizes more information in less axes than other techniques for direct ordering (Legendre \& Legendre 1998). The ordinations analyses were performed from a distance matrix calculated from the Sorensen's dissimilarity index (qualitative data) and Bray-Curtis's dissimilarity index (quantitative data). Additionally, we tested the difference in the ant species composition of treefall gaps and surrounding dense forests through a permutation test (10.000 permutations) based on analysis of similarities (ANOSIM) (Clarke 1993). Both the ordination and analysis of similarities were made through the software R Development Core 
Team (version 2.13.1). Finally, we use the first two axes of each ordination in a Multivariate Analysis of Covariance (MANCOVA) (MANCOVA), in order to evaluate the influence of temperature and interaction between the environment and the temperature in the ants composition through the software SYSTAT 10.0.0 (Wilkinson 1998).

To test the hypothesis that the coexistence of ant species in treefall gaps and surrounding dense forests is determined by competition, we used the co-occurrence index (C-Score) through the software EcoSim 7.72 (Gotelli $\&$ Entsminger 2009). In a competitively structured community, the observed $\mathrm{C}$-score index should be significantly higher than expected. When this index is less than expected competitive exclusion does not occur between the ant species (Gotelli 2000, Gotelli \& Entsminger 2009). We compared the observed C-score index with 5000 replicates generated by the null model where the species occurrences and sites are fixed. This null model assumes that the presence of a given ant species does not influence the occurrence of other species, i.e. there is no evidence for deterministic process influencing species distribution (Ribas \& Schoereder 2002, Gotelli \& Entsminger 2009).

\section{RESULTS}

In this study we collected 37 ant species representing eight genera and 4 subfamilies. The subfamily Myrmicinae had the greatest number of taxa (81.1\%), followed by Formicinae (8.1\%), Ectatomminae (5.4\%) and Ponerinae (5.4\%). We collected 14 ant species in treefall gaps and 21 ant species in surrounding dense forests, and only six species occurred in both environments. Eight species were exclusive to treefall gaps and 17 species were exclusive to surrounding dense forests (Table 1). However, there was no difference in the richness and abundance of ants by area between the environments (ANOVA, $\mathrm{P}>0.05)$, and both factors also did not vary with temperature and are not different between the environments (ANOVA, P>0.05) (Table 2).

The temperature range in dense forest (Mean $26,1^{\circ} \mathrm{C}-\operatorname{Min} 24,0^{\circ} \mathrm{C}$, Max $28.3^{\circ} \mathrm{C}$ ) was lower than in the treefall gaps (Mean $27,5^{\circ} \mathrm{C}-\operatorname{Min} 23,7^{\circ} \mathrm{C}$, $\operatorname{Max} 32.3^{\circ} \mathrm{C}$ ), and there was a difference in temperature variation per hour between the two environments $\left(\mathrm{F}_{(1.137)}=33.126\right.$; $\left.\mathrm{P}<0.001\right)$.

Despite the overlap in some points showed by the ordination analysis, the ant community of dense forest differs from the treefall gaps both qualitatively 
Table 1. Number of occurrences of ants collected in treefall gaps and surrounding dense forests environments in the months of June and July 2007 in a terra-firme forest in Central Amazon, Manaus city, Amazonas State, Brazil.

\begin{tabular}{|c|c|c|}
\hline \multirow[b]{2}{*}{ Ant species } & \multicolumn{2}{|c|}{ Number of occurrences } \\
\hline & Treefall gaps & Surrounding dense forests \\
\hline Camponotus femoratus (Fabricius 1804) & - & 19 \\
\hline Crematogaster sp1 & 25 & 10 \\
\hline Crematogaster sp2 & 2 & 4 \\
\hline Crematogaster sp3 & - & 4 \\
\hline Crematogaster sp4 & 13 & - \\
\hline Ectatomma quadridens (Fabricius 1793) & - & 1 \\
\hline Ectatomma tuberculatum (Olivier 1792) & 1 & - \\
\hline Odontomachus haematodus (Linnaeus 1758) & - & 1 \\
\hline Odontomachus scalptus Brown 1978 & 1 & - \\
\hline Paratrechina sp1 & 3 & 2 \\
\hline Paratrechina sp2 & 1 & - \\
\hline Pheidole sp1 & - & 3 \\
\hline Pheidole sp2 & - & 3 \\
\hline Pheidole sp3 & - & 7 \\
\hline Pheidole sp4 & - & 2 \\
\hline Pheidole sp5 & 1 & 2 \\
\hline Pheidole sp6 & - & 3 \\
\hline Pheidole sp7 & - & 5 \\
\hline Pheidole sp8 & - & 2 \\
\hline Pheidole sp9 & - & 1 \\
\hline Pheidole sp10 & - & 2 \\
\hline Pheidole sp11 & - & 1 \\
\hline Pheidole sp12 & 15 & 3 \\
\hline Pheidole sp 13 & - & 1 \\
\hline Pheidole sp 14 & 3 & - \\
\hline Pheidole sp 15 & 1 & - \\
\hline Pheidole sp16 & 6 & 1 \\
\hline Pheidole sp17 & 1 & - \\
\hline Pheidole sp18 & 1 & - \\
\hline Pheidole sp19 & 1 & - \\
\hline Pheidole sp20 & 1 & - \\
\hline Solenopsis geminata (Forel 1893) & 1 & - \\
\hline Solenopsis sp 1 & 1 & 4 \\
\hline Solenopsis sp2 & - & 3 \\
\hline Trachymyrmex cornetzi (Forel 1912) & - & 2 \\
\hline Trachymyrmex sp1 & - & 1 \\
\hline Trachymyrmex sp2 & 1 & 1 \\
\hline
\end{tabular}




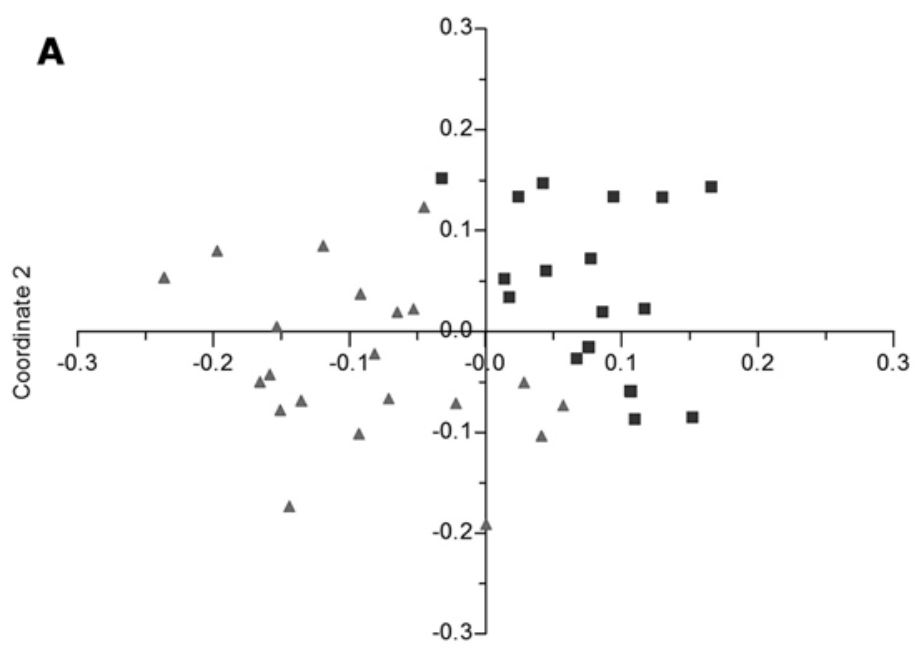

Coordinate 1

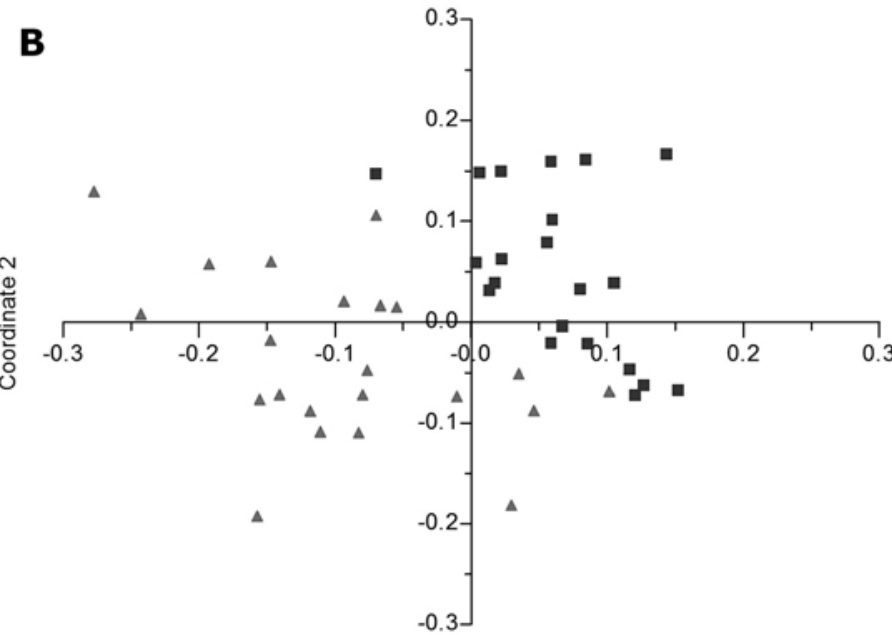

Coordinate 1

Fig. 1. Non-metric multidimensional scaling (NMDS) of ants collected in treefall gaps (triangles) and surrounding dense forests (squares) in June and July 2007 in a terra-firme forest in Central Amazon, Manaus city, Amazonas State, Brazil. This ordination analysis was calculated from the (A) Sorensen's dissimilarity index (Stress $=0.2631$; Axis $1+$ Axis $2=49.5 \%$ of explanation) and (B) Bray-Curtis's dissimilarity index (Stress $=0.2635$; Axis $1+$ Axis $2=49.3 \%$ of explanation). 
Table 2. General Linear Models (GLM) to assess the influence of temperature, the type of environment (treefall gaps and surrounding dense forests), and the interaction of both factors on the richness and abundance of ants.

\begin{tabular}{llllll}
\hline \hline Response & Effect & DF & Mean Squares & F-ratio & P-value \\
\hline \multirow{3}{*}{ Richness } & Environment & 1 & 2.043 & 1.250 & 0.269 \\
& Temperature & 1 & 0.242 & 0.148 & 0.702 \\
& Environment ${ }^{*}$ Temperature & 1 & 2.452 & 1.500 & 0.227 \\
& Error & 46 & 1.634 & & \\
& & & & & \\
Abundance & 1 & 2.492 & 1.885 & 0.176 \\
& Environment & 1 & 1.269 & 0.960 & 0.332 \\
& Environment ${ }^{*}$ Temperature & 1 & 2.771 & 2.096 & 0.154 \\
& Error & 46 & 1.322 & & \\
\hline \hline
\end{tabular}

(NMDS, followed by ANOSIM; $\mathrm{P}<0.001$ ) and quantitatively (NMDS, followed by ANOSIM; $\mathrm{P}<0.001$ ) (Fig. 1). In qualitative data, the temperature did not influence the species composition of ants (MANCOVA, Pillai-Trace: $\left.\mathrm{F}_{(0.007)}=1.037 ; \mathrm{P}=0.363\right)$, and the composition did not change with temperature differences between the environments (MANCOVA, PillaiTrace : $\left.\mathrm{F}_{(0.007)}=0.279 ; \mathrm{P}=0.345\right)$. For the quantitative matrix, there was no influence of temperature on the species composition of ants (MANCOVA, Pillai-Trace: $\left.\mathrm{F}_{(0.034)}=0.793 ; \mathrm{P}=0.459\right)$ and the composition did not change with temperature differences between the environments (MANCOVA, Pillai-Trace $\left.: \mathrm{F}_{(0.051)}=1.197 ; \mathrm{P}=0.312\right)$.

Our data indicate that competition does not seem to be the principal factor in structuring of ant communities in treefall gaps and surrounding dense forests. The simulations performed for the ant community associated with the treefall gaps showed that the observed C-score index is lower than expected $(\mathrm{P}=0.001)$ if the competition was a factor structuring the ant community (Fig. 2A). In ant community associated with dense forests, the simulations realized showed that the observed $\mathrm{C}$-score index lay within the $95 \%$ limits of random frequency obtained from the null model $(\mathrm{P}=0.75)$ (Fig. 2B). 

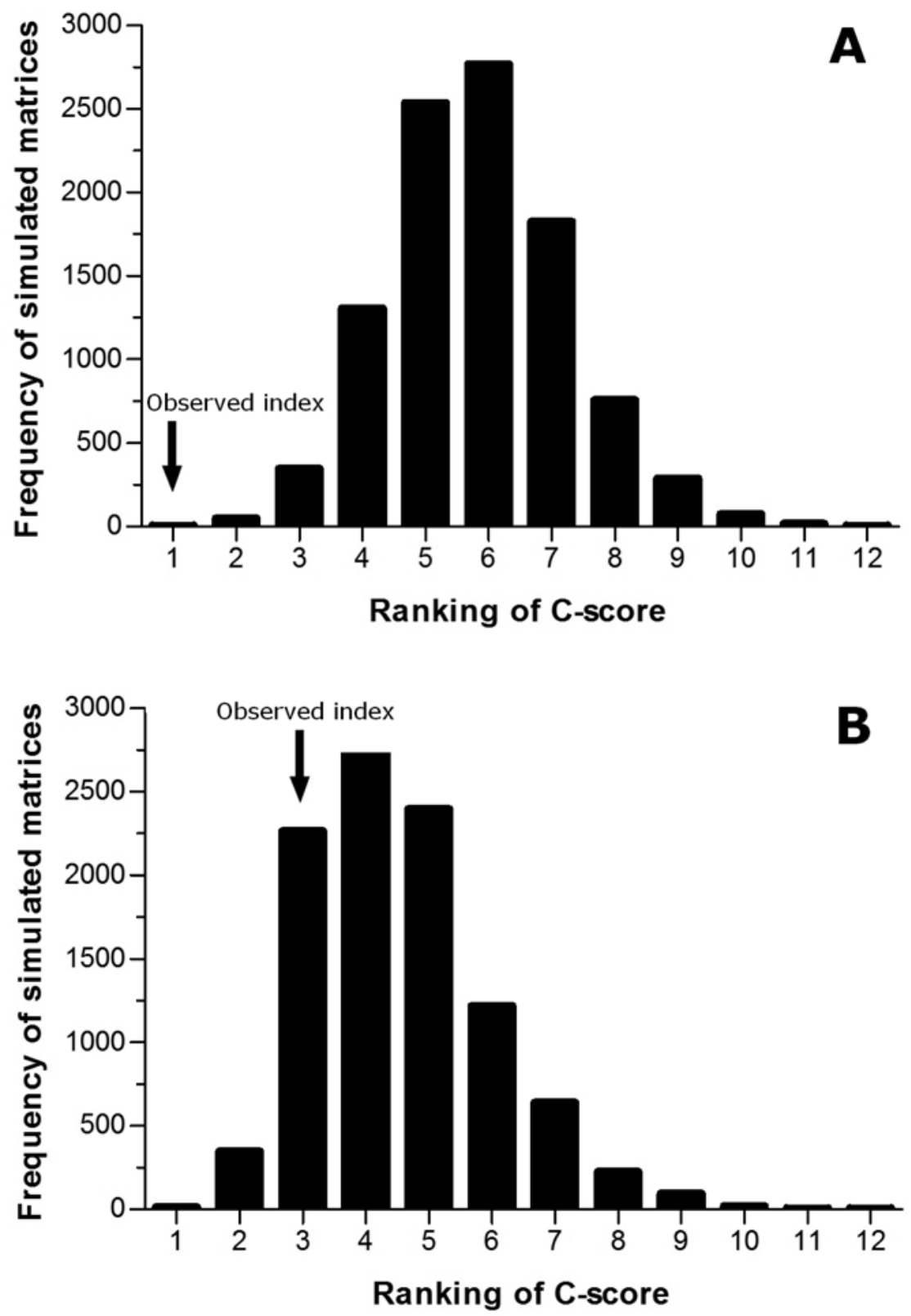

Fig.2. Frequency distribution of the co-occurrence C-score index obtained from 5000 replicates generated by the null model in the ant community associated with A) treefall gaps and B) surrounding dense forests in June and July 2007 in a terra-firme forest in Central Amazon, Manaus city, Amazonas State, Brazil. Arrows represent the observed C-score index. 


\section{DISCUSSION}

Many studies have shown the factors that determine the ant diversity in different spatial scales (Hölldobler \& Wilson 1990, Andersen 1997, Cerdá 1997, Gibb \& Hochuli 2002, Ribas et al. 2003, Floren \& Linsenmair 2005, Kaspari 2005). These factors act differently in different spatial scales and vegetation types (Santos et al. 2006). In this study, in a small spatial scale, even with the difference in the amplitude and the thermic variation between the treefall gaps and surrounding dense forests environments, we did not observe a modification of the ant community as a function of temperature, but just due to strong differences on habitat structure. Some studies have shown that the composition and foraging ants in treefall gaps environments are not only influenced by microclimatic factors, but also by the interaction of these factors with the structural complexity of vegetation in terms of availability of food and nesting sites (Greenslade \& Halliday 1983, Andersen 1986, Aguiar \& Monteza 1996, Basu 1997). Thus, many factors act together so that the composition of ant species differs between forest clearings and around tropical forests (Aguiar \&Montez 1996), as observed in our results. In regions with large climatic variations throughout the day and year, the temperature can directly influence the foraging strategy of ants, and change the hierarchical level between the dominant ant species (Herbers 1989, Hölldobler \& Wilson 1990, Cerdá et al. 1997, 1998).

On a broader level, some studies have shown that competition is the only or most important factor regulating the ant diversity (Room 1971, Andersen 1992, Majer et al. 1994, Acosta et al, 1995, Djieto-Lordon \& Dejean 1999, Delabie et al. 2000; Albrecht \& Gotelli 2001). However, variations in environmental conditions, ecological, spatial, beyond random events can modulate the importance of competition and the ant community structure in one site (Hölldobler \& Wilson 1990, Morrison 1996, Basu 1997). Our work corroborates with other work available in the literature that there is not substantial evidence that competition influences ant community structure at different spatial scales (Levings \& Traniello 1981, Fellers 1987, Ryti \& Case 1992, Punttila et al. 1996; Ribas \& Schoereder 2002). In treefall gap environments, there was a great co-occurrence of ant species, possibly due to the fact that most species in disturbed environments are resource and habitat 
generalists (Fowler 1990, Andersen 1995, King et al. 1998, Vasconcelos 1999, Silvestre et al. 2003, Dáttilo et al. 2011). That means limitation of a particular resource that can be dominated by some ant species does not necessarily cause the elimination of other species. So, the ants associated with these environments may use different food resources and change, even temporarily, their diets, avoiding competition and facilitating the co-occurrence (Herbers 1989, Yanoviak \& Kaspari 2000, Albrecht \& Gotelli 2001, Santos et al. 2006). On the other hand, in surrounding dense forests, the results showed that the co-occurrence observed lay within the $95 \%$ limits of random frequency and suggest that it is not always the biological processes which determines the spatial distribution of ants. Ribas \& Schoereder (2002) tested the hypothesis of competition structuring the ant community in 14 different tropical rain forests and also obtained through simulations by null models, and the results indicate that the ant mosaic theory of structuring the ant community does not apply to these regions. Given the high availability and spatial distribution of food resources, beyond the climatic conditions equilibrium, our study suggests that the structure of ant communities in tropical rainforests may really be stochastic or neutral within each environment (Floren \& Linsenmair 2000, Floren et al. 2001, Hubble 2001).

Finally, as individuals differ in the probability of colonizing a type of environment due to dispersal ability and the effects of variation between environments, we expect that the ant composition is different in treefall gaps and surrounding dense forest environments (Olden et al.2001, Bruna et al. 2011). The foraging and colonization of the environment immediately after the opening of the one treefall gap can be determining factors in the establishment of the colony as we observed, once ant species that occur in treefall gaps are different from the surrounding dense forests (Aguiar \& Monteza 1996). So, some generalist species colonize treefall gaps environments, while habitat specialists probably can not survive and/or establish nests. Additionally, the natural regeneration that occurs within the treefall gaps influencing important parameters of composition and distribution of the ant species that live there (Pearson et al. 2003). We suggest for future studies, assessment of how the regeneration of treefall gaps influence the processes of substitution and competition of ants inside the tropical rainforests, since such events are part of the natural dynamics of these forests. 


\section{ACKNOWLEDGMENTS}

We would like to thank Rafael V. Nunes, Rodrigo Nunes and Jéssica Falcão for theirs comments on earlier versions of this manuscript, and Biological Dynamics of Forest Fragments Project (BDFFP, INPA/Smithsonian Institute) by logistical support. We also thank Osmaildo Ferreira for her assistance during the fieldwork. Financial support was provided by Brazil's Conselho Nacional de Desenvolvimento Científico e Tecnológico (Grants 490518/2006-0 to TJI). WD thanks CAPES for his masters fellowship. This is publication 589 in the BDFFP technical series.

\section{REFERENCES}

Acosta, F., F. Lopez, \& J. Serrano. 1995. Dispersed versus central-place foraging: intra- and intercolonial competition in the strategy of trunk trail arrangement of a harvester ant. Am. Nat. 145: 389-411.

Adams, E.S. 1994. Territory defense by the ant Azteca trigona: maintenance of an arboreal ant mosaic. Oecol. 97: 202-208.

Aguiar, C.M.L. \& J.I. Monteza. 1996. Comparação da fauna de formigas (Hymenoptera, Formicidae) associada a árvores em áreas de clareira e floresta intacta na Amazônia Central. Sitientibus 15: 167-174.

Albrecht, M., \& N.J. Gotelli. 2001. Spatial and temporal niche partitioning in grassland ants. Oecol. 126: 34-141.

Allen, P.S., \& S.E. Meyer. 1998. Ecological aspects of seed dormancy loss. Seed. Sci. Res. 8(2): 183-191.

Almeida, S. 1989. Clareiras naturais na Amazônia Central: Abundância, distribuição, estrutura e aspectos da colonização. (MSc. Dissertation, Instituto Nacional de Pesquisas da Amazônia, Manaus) 103 pp.

Andersen, A.N. 1986. Patterns of ant community organization in mesic southeastern Australia. Aust .J. Ecol. 11: 87-97.

Andersen, A.N. 1991. Parallels between ants and plants: implications for community ecology. In: C.R. Huxley, \& D.F. Cutler eds., Ant-Plant Interactions. Oxford University Press, Oxford, UK: 539-558.

Andersen, A.N. 1992. Regulation of "momentary" diversity by dominant species in exceptionally rich ant communities of the Australian seasonal tropics. Am. Nat. 140: 401-420.

Andersen, A.N. 1995. A classification of Australian ant communities, based on functional groups which parallel plant life-forms in relation to stress and disturbance. J. Biog. 20: $15-29$.

Andersen, A.N. 1997. Using ants as bioindicators: multiscale issues in ant community ecology. Cons. Ecol. 1: 1-8. 
Andrade, A.C.S., A.F. Souza, F.N. Ramos, T.S. Pereira, \& A.P.M. Cruz. 2000. Germinação de sementes de jenipapo: temperatura, substrato e morfologia do desenvolvimento pósseminal. Pesq. Agro. Bras. 35(3): 609-615.

Basu, P. 1997. Seasonal and spatial patterns in ground foraging ants in a rain forest in the Western Ghats, India. Biotrop. 29: 489-500.

Benson, W.W., \& A.Y. Harada. 1988. Local diversity of tropical and temperate ant faunas (Hymenoptera: Formicidae). Acta Amaz. 18: 275-289.

Bestelmeyer, B.T. 2000. The trade-offbetween thermal tolerance and behavioural dominance in a subtropical South American ant community. J. Anim. Ecol. 69: 998-1009.

Brokaw, N.V.L. 1985. Gap-phase regeration in a tropical forest. Ecol. 66(3): 682-687.

Brown, N. 1993. The implications of climate and gap microclimate for seedling growth conditions in a Bornean lowland forest. J. Trop. Ecol. 9: 153-168.

Brown, K.S. 1997. Diversity, disturbance, and sustainable use of Neotropical forests: insects as indicators for conservation monitoring. J. Ins. Conserv. 1: 25-42.

Bruna, E.M., T.J. Izzo, B. Inouye, M. Uriarte, \& H. L. Vasconcelos. 2011. Assymetric dispersal and colonization success of Amazonian plant-ant queens. Plos ONE 6(8): e22937.

Cerdá, X, J. Retana, \& Cros, S. 1997. Thermal disruption of transitive hierarchies in Mediterranean ant communities. J. Anim. Ecol. 66: 363-374.

Cerdá, X, J. Retana, \& A. Manzaneda. 1998. The role of competition by dominants and temperature in the foragingof subordinate species in Mediterranean ant communities. Oecol. 117: 404-412.

Chesson, P. 2000. Mechanisms of maintenance of species diversity. Ann. Rev. Ecol. Syst. 31: 343-366.

Clarke, K.R., R.M. Warwick, \& B.E. Brown. 1993. An index showing breakdown of seriation, related to disturbance, in a coral reef assemblage. Mar. Ecol. Prog. Ser. 102: 153-160.

Dáttilo, W, E.C. Marques, Falcão, J.C.F., \& D.D.O. Moreira. 2009. Interações mutualísticas entre formigas e plantas. EntomoBrasilis 2: 32-36.

Dáttilo, W., N. Sibinel, J.C.F. Falcão, \& R.V. Nunes. 2011. Mirmecofauna em um fragmento de Floresta Atlântica urbana no município de Marília, SP, Brasil. Biosci. J. 27(3): 494504.

Delabie, J.H.C., D. Agosti, \& I.C. Nascimento. 2000. Litter ant communities of the Brazilian Atlantic rain forest region. In: D. Agosti,J.D. Majer, L. Alonso, \& T. Schultzed., Sampling ground-dwelling ants: case studies from de world's rain forests. Curtin University School of Environmental Biology, Perth, Australia: 1-17.

Djieto-Lordon, C., \& A. Dejean. 1999. Tropical arboreal ant mosaics: innate attraction and imprinting determine nest site selection in dominant ants. Behav. Ecol. Sociobiol. 45: 219-225.

Ekstam, B., \& A. Forseby. 1999. Germination response of Phragmites australis and Typha latifolia to diurnal fluctuations in temperature. Seed. Sci. Res. 9: 157-163.

Fellers, J.H. 1987. Interference and exploitation in a guild of woodland ants. Ecol. 68: 14661478. 
Fisher, B.L. 1999. Improving inventory efficiency: a case study of leaf-litter ant diversity in Madagascar. Ecol. App. 9: 714-731.

Floren, A. \& K.E. Linsenmair. 2000. Do ant mosaics exist in pristine lowland rain forests? Oecol. 123: 129-137.

Floren, A., Freking, A., Biehl, M., \& K.E. Linsenmair 2001. Anthropogenic disturbance changes the structure of arboreal tropical ant communities. Ecograp. 24: 547-554.

Floren, A., \& K.E. Linsenmair. 2005. The importance of primary tropical rain forest for species diversity: an investigation using arboreal ants as an example. Ecosyst. 8: 559-567.

Fowler,H.G.,J.V.E. Bernadi,J.H.C. Delabie, L.C. Forti \&V.Pereira-da-Silva. 1990. Major ant problems of South America. In: R.K. Vander-Meer, K. Jaffé, \& A. Cedeno eds., Applied myrmecology: A world perspective. Westview Press, Colorado, USA: 14-53.

Fowler, H.G., L.C. Forti, C.R.F. Brandão, J.H.C. Delabie, \& H.L. Vasconcelos. 1991. Ecologia nutricional de formigas. In: A.R. Panizzi, \& J.R.P. Parra eds., Ecologia nutricional de insetos. Editora Manole, São Paulo, Brazil: 131-223.

Gause G.F. 1934. The struggle for existence. Baltimore: Williams \& Wilkins Press 163 pp.

Gibb, H., \& D.F. Hochuli. 2002. Habitat fragmentation in an urban environment: large and small fragments support different arthropod assemblages. Biol. Conserv. 106: 91-100.

Gotelli, N.J. 2000. Null model analysis of species co-occurrence patterns. Ecol. 81: 26062621.

Gotelli, N.J., \& G.L. Entsminger. 2009. EcoSim: Null models software for ecology. Version 7.2. Acquired Intelligence Inc. \& Kesey-Bear. Webpage http://garyentsminger.com/ ecosim/index.htm

Gotelli, N.J., A.M.Ellison, R.R. Dunn, \& N.J. Sanders. 2011. Counting ants (Hymenoptera: Formicidae): biodiversity sampling and statistical analysis for myrmecologists. Myrmecol. News 15: 13-19.

Greenslade, P.J.M., R.B. \& Halliday. 1983. Colony dispersion and relationships of meat ants Iridomyrmex purpureus and allies in an arid locality in South Australia. Insectes Soc. 30: 82-99.

Herbers, J.M. 1989. Community structure in north temperate ants: temporal and spatial variation. Oecol. 81:201-211.

Hölldobler , B., \& E.O. Wilson. 1990. The ants. Massachusets: Harvard University Press $733 \mathrm{pp}$.

Hubbell, S.P. 2001. A unified neutral theory of biodiversity and biogeography. New Jersey: Princeton University Press 375 pp.

Kaspari, M. 2005. Global energy gradients and size in colonial organisms: worker mass and worker number in ant colonies. Proc. Natl. Acad. Sci. 102: 5079-5083.

King,J.R., A.N. Andersen, \& A.D. Cutter. 1998. Ants as bioindicators of habitat disturbance: validation of the functional group model for Australia's humid tropics. Biodivers. Conserv. 7: 1627-1638. 
Laurance, W.F. 2001. The hyper-diverse flora of the Central Amazon: an overview. In: R.O. Bierregaard, C.Gascon, T.E. Lovejoy, \& R. Mesquita eds., Lessons From Amazonia: The Ecology and Conservation of a Fragmented Forest. Yale Universit Press, New Haven, USA: $47-53$.

Leal, I.R., \& B.C. Lopes. 1992. Estrutura das comunidades de formigas (Hymenoptera: Formicidae) de solo evegetação no Morro da Lagoa da Conceição, Ilha de Santa Catarina, SC. Biotemas 5(1): 107-122.

Legendre, P., \& L. Legendre. 1998. Numerical ecology. Third English edition. Amsterdam: Elsevier Press 870 pp.

Levings, S.C., \& J.F.A. Traniello. 1981. Territoriality, nest dispersion, and community structure in ants. Psyche 88: 265-319.

Longino, J.T., J. Coddington, \& R.K. Colwell. 2002. The ant fauna of a tropical rain forest: estimating species richness in three different ways. Ecol. 83: 689-702.

Lopez, F., J.M. Serrano, \& F.J. Acosta. 1994. Parallels between the foraging strategies of ants and plants. Trends Ecol. Evol. 9: 150-153.

Lovejoy, T.E., \& R.O. Bierregaard. 1990. Central Amazonian forests and the minimum critical size of ecosystems project. In: A.H. Gentry ed., Four neotropical rainforests. Yale University Press, New Haven, USA: 60-71.

Majer, J.D. \& P. Camer-Pesci. 1991. Ants species in tropical australian tree cropsand native ecosystems - is there a mosaic? Biotrop. 23(2): 173-181.

Majer, J.D., J.H.C. Delabie, \& M.R.B. Smith. 1994. Arboreal ant community patterns in Brazilian cocoa farms. Biotrop. 26: 73-83.

MacArthur, R., \& Levins, R. 1964. Competition, habitat selection and character displacement in a patchy environment. Proc. Acad. Nat. Sci. 51: 1207-1210.

Marsh, A.C. 1988. Activity patterns of some Namib desert ants. J. Arid. Environ. 14: 6173.

Morrison, L. W. 1996. Community organization in a recently assembled fauna: The case of Polynesian ants. Oecol. 107: 243-256.

Olden, J.D., D.A. Jackson, \& P.R. Peres-Neto. 2001. Spatial isolation and fish communities in drainage lakes. Oecol. 127: 572-585.

Parr, C.L., B.J. Sinclair, A.N. Andersen, K.J. Gaston, \& S. L.Chown. 2005. Constraint and competition in assemblages: a cross continental and modeling approach for ants. Am. Nat. 165:481-494.

Pearson, T.R.H., D.F.R.P. Burslem, R.E. Goeriz, \& J.W. Dalling. 2003. Interactions of gap size and herbivory on establishment, growth and survival of three species of neotropical pioneer trees. J. Ecol. 91:785-796.

Porter, S.D., \& W.R. Tschinkel. 1993. Fire ant thermal preferences: behavioral control of growth and metabolism. Behav. Ecol. Sociobiol. 32: 321-329.

Probert, R.J. 1993. The role of temperature in germination ecophysiology. In: M. Fenner ed., Seeds: the ecology of regeneration in plant communities. CAB International Press, Wallingford, USA: 285-326. 
Punttila, P., Y. Haila, \& H. Tukia. 1996. Ant communities in taiga clearcuts: habitat effects and species interactions. Ecograp. 19: 16-28.

Reyes-Lopes, J., N. Ruiz, \& J. Fernándes-Haeger. 2003. Community structure of ground-ants: The role of single trees in a Mediterranean pastureland. Acta Oecol. 24: 195-202.

Ribas, C.R., \& J.H. Schoereder. 2002. Are all ant mosaics caused by competition? Oecol. 131: 606-611.

Ribas, C.R., J.H. Schoereder, M. Pic, \& S.M. Soares. 2003. Tree heterogeneity, resource availabity, and larger scale processes regulating arboreal ant species richness. Austr. Ecol. 28:305-314.

Ribeiro, M.N.G. 1976. Aspectos Climatológicos de Manaus. Acta Amaz. 6(2): 229-233.

Romero, H., \& K. Jaffé. 1989. A comparison of methods for sampling ants (Hymenoptera, Formicidae) in savannas. Biotrop. 21: 348-325.

Room, P.M. 1971. The relative distributions of ant species in Ghana's cocoa farms. J. Anim. Ecol. 40: 735-751.

Ryti, R.T., \& T.J. Case. 1992. The role of neighborhood competition in the spacing and diversity of ant communities. Am. Nat. 139: 355-374.

Santos, I.A., Ribas, C.R. Shoereder, J.H. 2006. Biodiversidade de formigas em tipos vegetacionais brasileiros: o efeito das escalas espaciais. In: E.F. Vilela, I.A. Santos, J.H. Schoereder, J.E. Serrão, L.A.O. Campos, J. Lino-Neto eds., Insetos Sociais: Da biologia á aplicação. Editora UFV, Viçosa, Brazil: 397-435.

Silvestre, R., C.R.F. Brandão, R.R. Silva. 2003. Grupos funcionales de hormigas: El caso de los gremios del cerrado. In: F. Fernández ed., Introducción a las hormigas de la región Neotropical. Instituto de Investigación de Recursos Biológicos Alexandervon Humboldt, Bogotá, Colombia: 113-148.

Tavares, A.A., P.C. Bispo, \& A.C.S. Zanzini. 2001. Comunidades de formigas epigéicas (Hymenoptera, Formicidae) em áreas de Eucalyptus cloeziana F. Muell e de vegetação nativa numa região de cerrado. Rev. Bras. Entomol. 45(3): 251-256.

Uhl, C.K., N. Dezzeo, \& P. Maquirino. 1988. Vegetation dynamics in Amazonian treefall gaps. Ecol. 69: 751-763.

Vasconcelos, H.L. 1999. Effects of forest disturbance on the structure of ground-foraging ant communities in central Amazonia. Biodiv. Conserv. 8: 409-420.

Vasconcelos, H., \& J.H.C. Delabie. 2000. Ground ant communities from central Amazonia forest fragments. In: D. Agosti, J.D. Majer, L. Alonso, \& T. Schultz eds., Sampling ground-dwelling ants: case studies from de world's rain forests. Curtin University School of Environmental Biology, Perth, Australia: 59-70.

Vázquez-Yanes, C., \& Orozco-Segovia, A. 1982. Seed germination of a tropical rain forest pioneer tree (Heliocarpus donnell-smithii) in response to diurnal fuctuation of temperature. P. Physiol. 56: 295-298.

Ward, P.S. 2006. Ants. Curr. Biol. 16: 152-155.

Wehner, R., A.C. Marsh, S. Wehner. 1992. Desert ants on a thermal tightrope. Nature 357: 586-587. 
Whitmore, T.C. 1978. Gaps in the forest canopy. In: P.B. Tomlinson, \& M.H.Zimmermann eds., Tropical trees as living systems. Cambridge University Press, New York, USA: 639-655.

Wilkinson, L. 1998. Systat: the system for statistics. Illinois: SYSTAT Inc. Evaston. 822 pp.

Wilson, E.O. 1959. Some ecological characteristics of ants in New Guinean rain forest. Ecol. 40: 437-447.

Yanoviak, S.P., \& Kaspari, M. 2000. Community structure and the habitat templet: ants in tropical forest canopy and litter. Oikos 89: 259-266. 
